Departement für Kleintiere, Abteilung für Radio-Onkologie der Vetsuisse-Fakultät Universität Zürich

Direktor: Prof. Dr. Jean-Michel Hatt

\title{
Use of Epothilone B (Patupilone) in Refractory Lymphoma and Advanced Solid Tumors in Dogs
}

\author{
Inaugural-Dissertation \\ zur Erlangung der Doktorwürde der \\ Vetsuisse-Fakultät Universität Zürich \\ vorgelegt von \\ Valeria Sabina Meier \\ Tierärztin \\ von Hundwil AR \\ genehmigt auf Antrag von \\ PD Dr. Carla Rohrer Bley, Referentin
}


Inhaltsverzeichnis

Dissertationsschrift........................................................................................................1

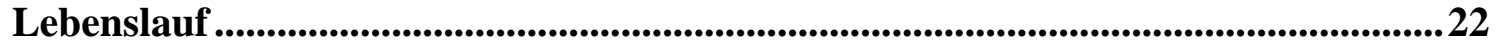

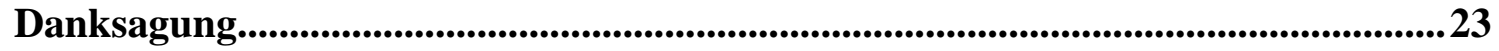


USE OF EPOTHILONE B (PATUPILONE) IN REFRACTORY LYMPHOMA AND ADVANCED SOLID TUMORS IN DOGS

V. Meier ${ }^{1}$, C. Geigy ${ }^{1}$, N. Grosse ${ }^{1}$, P. McSheehy ${ }^{2}$, C. Rohrer Bley ${ }^{1}$

${ }^{1}$ Division of Radiation Oncology, Vetsuisse Faculty University of Zurich, Zurich, Switzerland

${ }^{2}$ Novartis Institutes for BioMedical Research, Novartis Pharma AG, Basel, Switzerland

Short Title: Epothilone B in dogs

Key Words: Microtubule-stabilizing agents, epothilones, chemotherapy

Abbreviations: MSA: microtubule-stabilizing agents; MTD: maximally tolerated dose; AE:

adverse effects; CR: complete response; PR: partial response; SD: stable disease; PD:

progressive disease

\section{Corresponding Author:}

Valeria Meier

Division of Radiation Oncology

Vetsuisse Faculty, University of Zurich

Winterthurerstrasse 260

CH-8057 Zurich

Switzerland

vmeier@vetclinics.uzh.ch

This study was performed at the Vetsuisse Faculty, University of Zurich, Zurich, Switzerland.

This study was not funded. 
This study was presented as an abstract at the 21st ECVIM-CA 2011 in Seville and the 57th DVG-Vet-Congress 2011 in Berlin.

\title{
Acknowledgments:
}

We thank Yuko Goto-Koshino, University of Tokyo for the canine malignant lymphoma Tcell line; Erin Dickerson, University of Wisconsin, for the canine hemangiosarcoma cell line; Barbara Rutgen, University of Vienna, for her support with the lymphoma cell line. This study was partially performed using the logistics of the Center for Clinical Studies at the Vetsuisse Faculty, University of Zurich: we thank Marina Meli and Regina HofmannLehmann for their support.

\begin{abstract}
:
Background: The epothilones are microtubule-stabilizing agents with promising antitumor effect in refractory and metastatic tumors in humans. The toxicity profile is considered more favorable than in taxanes. The safety of epothilone B (patupilone) has not been evaluated in tumor-bearing dogs.
\end{abstract}

Objectives: To evaluate the inhibition of proliferation in canine tumor cells after patupilone treatment. To assess toxicity profile and maximally tolerated dose of patupilone in dogs with refractory tumors.

Animals: Twenty client-owned dogs with various malignancies.

Methods: The inhibition of proliferation was assessed with a proliferation assay in vitro in canine hemangiosarcoma and lymphoma cell lines. In the prospective clinical study, dogs received patupilone intravenously once a week for two treatments (= one treatment cycle). Dose was escalated with three dogs per cohort and $20 \%$ increments. Adverse effects were graded according to the VCOG-CTCAE v1.0.

Results: Both canine cell lines were sensitive to patupilone with approximately $50 \%$ decrease 
of proliferative activity at $0.2-1 \mathrm{nM}$. In vivo, dose-limiting adverse effects occurred at 3.3 $\mathrm{mg} / \mathrm{m}^{2}$; main adverse effects were diarrhea, anorexia, vomiting, and nausea. Neither neutropenia nor peripheral neuropathy was observed. Maximally tolerated dose for two patupilone administrations once weekly IV is $2.76 \mathrm{mg} / \mathrm{m}^{2} .3 / 11 \mathrm{dogs}$ receiving more than one treatment cycle showed partial remission in the short period of observation.

Conclusions and Clinical Importance: Canine tumor cells show inhibition of proliferation to patupilone in vitro. Clinically, a dose of $2.76 \mathrm{mg} / \mathrm{m}^{2} \mathrm{IV}$ is well tolerated in dogs with spontaneously occurring tumors. 
Epothilones are potent nontaxoid microtubule-stabilizing agents (MSA) of bacterial origin sharing the binding site on $\beta$-tubulin with the taxanes, which belong to the most potent antineoplastic agents. ${ }^{1,2}$ MSA interfere with microtubule function in the proliferating cell by preventing the shortening of microtubules, resulting in a permanent or transient cell cycle arrest at the $\mathrm{G}_{2} / \mathrm{M}$-phase which leads to apoptosis. ${ }^{1,2}$ Ixabepilone ${ }^{\mathrm{a}}$ is the first compound of the epothilones to be approved as monotherapy or in combination with capecitabine for the treatment of women with metastatic breast cancer and demonstrates activity in tumors that show resistance towards anthracycline and taxane standard therapy. ${ }^{2,3}$ Compared to the taxanes, epothilones are described to be more potent and possess several advantages such as increased solubility, low susceptibility to drug efflux transporters (for example p-glycoprotein-mediated chemoresistance), and a more tolerable toxicity profile in human patients, which favors their development and makes them promising agents for further use in dogs as well. ${ }^{2,4}$ Patupilone (EPO906) is a natural, water-soluble epothilone B extracted from mycobacterium sorangium cellulosum and is the most active variant of the natural epothilones. The efficacy of patupilone is based on not only targeting tumor cells, but also the vasculature and angiogenesis of solid tumors. ${ }^{5,67}$ Patupilone was tested as a phase III monotherapy agent against ovarian cancer in human patients and other epothilones are currently undergoing a wide spectrum of single and combined treatment modality in phase II and phase III studies (e.g. for recurrent glioblastoma multiforme, breast cancer brain metastases,

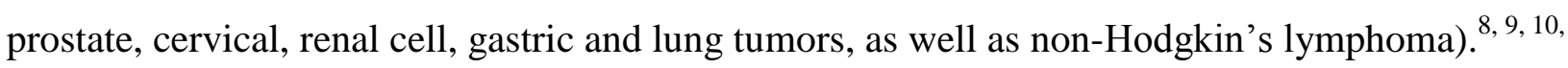
11,12

In order to introduce this promising antineoplastic substance group into veterinary medicine, the objectives of this study were 1) to evaluate, whether patupilone shows in vitro efficacy against canine tumor cell lines and 2) to determine the adverse effect (AE) profile and the maximally 
tolerated dose (MTD) for IV administration in dogs with various spontaneously occurring, treatment-refractory tumors.

\section{Material and Methods:}

\section{In Vitro Study:}

Canine Tumor Cell Lines. A canine malignant T-cell lymphoma cell line (CL-1) and a canine hemangiosarcoma cell line were used. ${ }^{13,14}$ CL-1 cells were cultured in RPMI 1640 with 1\% (v/v) stable glutamine $^{\mathrm{b}}, 10 \%(\mathrm{v} / \mathrm{v})$ fetal bovine serum ${ }^{\mathrm{c}}$, and $1 \%(\mathrm{v} / \mathrm{v})$ penicillin-streptomycin ${ }^{\mathrm{d}}$. Hemangiosarcoma cells were cultured in D-MEM/F-12 containing 1\% (v/v) L-glutamine ${ }^{\mathrm{e}}, 10 \%$ (v/v) fetal bovine serum ${ }^{\mathrm{f}}$, and $1 \%(\mathrm{v} / \mathrm{v})$ antibiotic-antimycotic ${ }^{\mathrm{g}}$ solution. All cells were incubated at $37^{\circ} \mathrm{C}$ in a humified incubator with $5 \% \mathrm{v} / \mathrm{v} \mathrm{CO}_{2}$.

Study Drug. Patupilone (epothilone B) was provided by Novartis Pharma, Basel, Switzerland. In order to obtain the stock solution, patupilone was dissolved in DMSO to a concentration of $1 \mathrm{mM}$ and further stored at $2-8^{\circ} \mathrm{C}$. Immediately before addition to cell lines, stock solution was diluted in culture medium in order to achieve the appropriate concentrations. Final DMSO concentrations used in the assays were in the nanomolar range $(\leq 0.0001 \%)$ and were considered to be negligible.

Cell Proliferation Assays. The proliferative activity of tumor cells was assessed with the colorimetric alamarBlue ${ }^{\circledR}$ assay ${ }^{\mathrm{h}}$ according to the protocol of the manufacturer. AlamarBlue ${ }^{\circledR}$ assesses metabolic activity of living cells by measurement of spectral absorption. Proliferation assays were performed in 96-well plates with $1 \times 10^{4}$ and $0.75 \times 10^{4}$ cells/well for CL-1 and hemangiosarcoma cell lines, respectively. Prior to the experiment, optimization assays (cell number) were performed to optimize the absorbance reading for spontaneous proliferation (i.e. proliferation at $0 \mathrm{nM})$. Each well contained $100 \mu \mathrm{l}$ of cell suspension in the concentration 
mentioned above, wells used as blank controls contained $100 \mu \mathrm{l}$ of media only. After a 24 hour incubation period, the cells were treated with $10 \mu \mathrm{l}$ of increasing concentrations of patupilone, control cells ( $0 \mathrm{nM})$ and blank wells (media only) were treated with $10 \mu \mathrm{l}$ of plain medium. Absorbance was measured in triplicates before and 24, 48, and 72 hours after patupilone treatment at 570 and $630 \mathrm{~nm}$ using the spectrophotometer SpectraMax ${ }^{\circledR}$ Plus $^{384}$ Absorbance Microplate Reader ${ }^{\mathrm{i}}$ and SoftMax ${ }^{\circledR}$ Pro 4.8 Software $^{\mathrm{j}}$ after a 6-hour incubation period of alamarBlue ${ }^{\circledR}$ dye. Background absorbance of cell media was subtracted. All assays were repeated as independent experiments at least thrice. The approximate $50 \%$ decrease of proliferative activity was derived from graphical plotting of data.

\section{In Vivo Study:}

Patient Eligibility Criteria. Dogs presented to the Vetsuisse Faculty, University of Zurich, Switzerland with histologically or cytologically confirmed neoplastic disease were prospectively enrolled in this study if they were refractory to standard of care treatment, if the owner declined other treatment, or if no established standard of care existed. In order to meet inclusion criteria, dogs required a modified Karnofsky's score of $\leq 1$, adequate hematologic, renal, and hepatic function and absence of any serious systemic disorder incompatible with the study at the discretion of the investigators. ${ }^{15}$ Prior chemotherapy treatment had to be terminated at least two weeks before start of the study. Written owner consent was obtained and the study was approved by the Animal Ethics Council of the Canton of Zurich, Switzerland.

Study Design and Drug Administration. This trial was a phase I dose-escalating, open-label assessment of adverse effects (AE) of patupilone in client-owned dogs with spontaneously occurring tumors. Safety was assessed on enrolment of at least three dogs into dose-escalating cohorts using a traditional $3+3$ design. ${ }^{16,17}$ Escalation was performed according to Vail ${ }^{17}$ where the dose was escalated if none of three dogs of one dose cohort developed dose-limiting AE as 
defined according to the VCOG-CTCAE v1.0. ${ }^{18}$ If one of the three dogs of a cohort experienced a dose-limiting $\mathrm{AE}$ or if the second treatment had to be delayed $\geq 5$ days due to grade 2 toxicosis, then at least three more dogs were included at the same dose level. Dose escalation was stopped, if two or more dogs of a cohort of three, or an extended cohort of six patients, respectively, developed dose-limiting AE or a treatment delay. This dose level was the maximally administered dose. The maximally tolerated dose (MTD) was defined as the highest dose level in which no more than one of six dogs develops a dose-limiting AE.${ }^{17}$ Escalation steps occurred in increments of $20 \%$ of the previous dose. Starting dose was $1.6 \mathrm{mg} / \mathrm{m}^{2}$, based on $50 \%$ of the MTD of experimental beagle dog data.

Treatment schedule consisted of two IV administrations of the drug once weekly (= one treatment cycle). In turn, dogs were evaluated every week for adverse effects and tumor response. If no progression was noted, treatment with patupilone was continued at the same dose level. Patupilone (epothilone B) for in vivo use was provided by Novartis Pharma, Basel, Switzerland as vials concentrate liquid of $10 \mathrm{mg} / 4 \mathrm{~mL}$. In order to prepare the epothilone B for administration, the concentrate was diluted with normal saline, to obtain a concentration of 1 $\mathrm{mg} / \mathrm{mL}$. The calculated dose was given via IV infusion in parallel to $100 \mathrm{~mL} 0.9 \%$ saline over a 10-20-minute interval.

Supportive care (e.g. antiemetics, antidiarrheals) was administered after occurrence of AE and was provided prophylactically after the next administration of drug. Medication for disease unrelated co-morbidity or further supportive care including steroids and non steroidal antiinflammatory drugs (NSAIDs) that had been administered at study entry and under which the dogs had shown progressive disease prior to study entry were continued. Antibiotics were prescribed in case of ulceration of tumor, analgesics for tumor-associated pain were allowed, and dogs with mast cell tumors at risk of histamine release received H1- and H2-blocking agents. 
Assessment of Adverse Effects. Dogs were evaluated for signs of intoxication weekly before each treatment, and one week after the last chemotherapy. Evaluation of severity of toxicoses to determine MTD was done after the first and second patupilone dose only. AE were monitored by performing a physical examination, complete blood count (CBC) and serum biochemistry at each scheduled appointment and by grading the dogs according to the Modified Karnofsky's Performance Criteria. ${ }^{15}$ Owners were asked to keep a log at home. Blood results and signs of $\mathrm{AE}$ were graded according to the VCOG-CTCAE v1.0. ${ }^{18}$ Unacceptable AE leading to discontinuation of the trial was defined as $\geq$ grade 3 toxicosis, except hematological $\mathrm{AE}$, where $\geq$ grade 4 was considered unacceptable. Because this trial included heavily pretreated patients with an advanced stage of disease, a baseline status using the same criteria was recorded for each dog before start of the trial.

Tumor Response Assessment. Due to the dose-escalating nature of this trial, response to treatment was only a secondary goal. Tumor size (locoregional and systemic) was assessed at study entry, before each drug administration and one week after the last treatment by means of caliper measurements and additional diagnostic imaging according to the tumor. In nonmetastatic tumors, clinical staging (thoracic radiographs, abdominal ultrasound) was performed at study entry and comparable re-evaluations took place after two and four patupilone administrations to exclude disease progression by means of systemic extension. Response was assessed as follows: in dogs with multicentric lymphoma, criteria according to VCOG consensus document for peripheral nodal lymphoma in dogs were used. ${ }^{19}$ Lymph nodes were measured using calipers and the mean sum of the longest diameter of a maximum of five target lesions was calculated. In dogs with other solid tumors, response was measured according to the revised RECIST guideline v1.1. ${ }^{20}$ The sum of diameters of all target lesions was calculated and reported as the baseline sum diameter. According to both guidelines, responses were considered to be 
complete if all target lesions had disappeared (or lymph nodes were of normal size, respectively), partial (PR) if a 30\% decrease of the sum of target lesion diameters occurred, or progressive (PD) if new lesions occurred or if there was an increase of at least $20 \%$ in the sum of target lesion diameters, taking as reference the smallest sum on study. ${ }^{21}$ Dogs that neither showed sufficient shrinkage to qualify for PR nor sufficient increase to qualify for PD were considered to have stable disease $(\mathrm{SD}){ }^{19,20}$

\section{Results:}

\section{In Vitro Study:}

Cell Proliferation Assays. In the two canine cell lines tested, 50\% decrease of proliferative activity was found to be in the range of $1 \mathrm{nM}$ in canine hemangiosarcoma and $0.2 \mathrm{nM}$ in malignant lymphoma cells (figure 1). Compared to drug sensitive human cell lines, the tested cell lines showed sensitivity to patupilone..$^{22,23}$

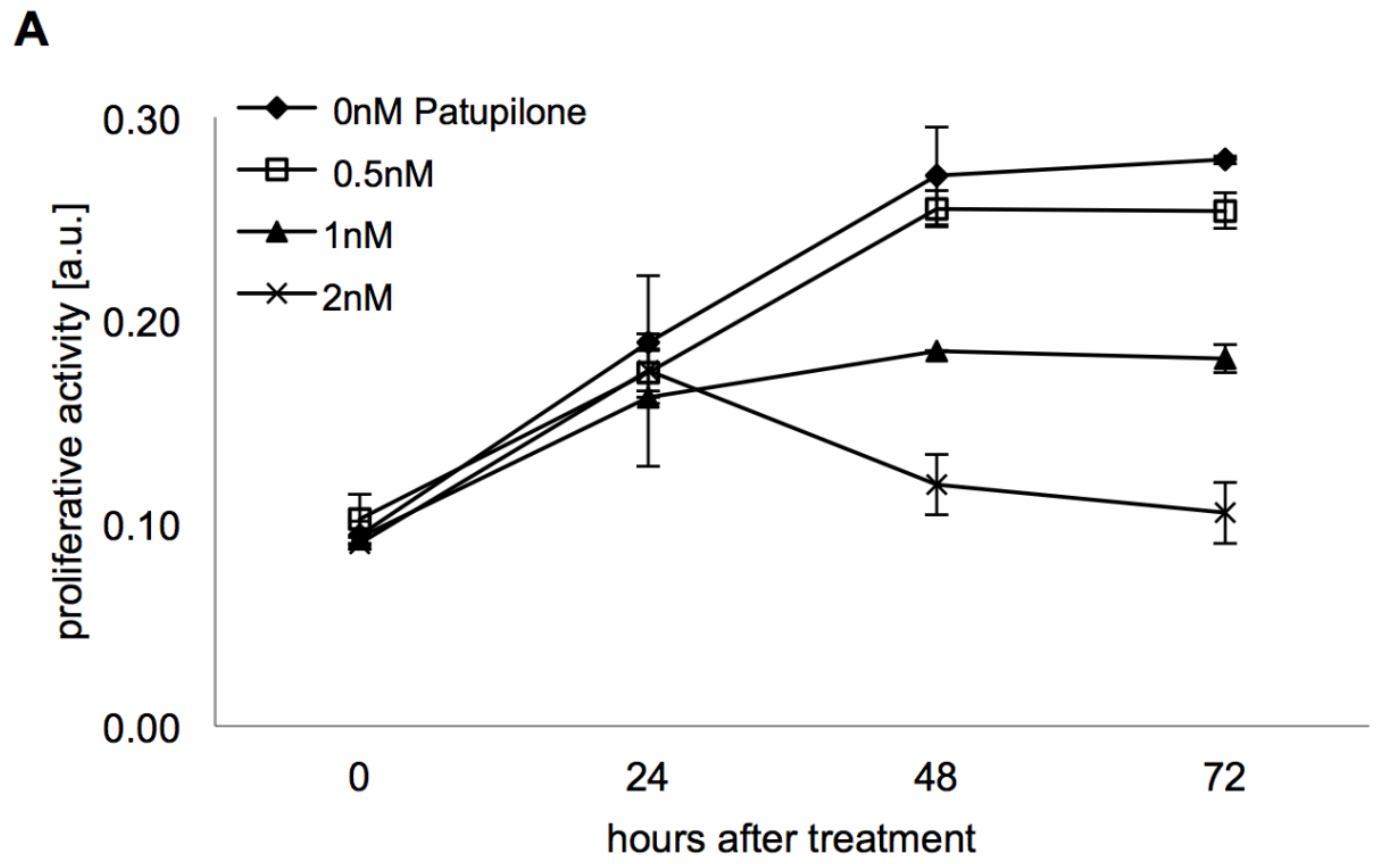




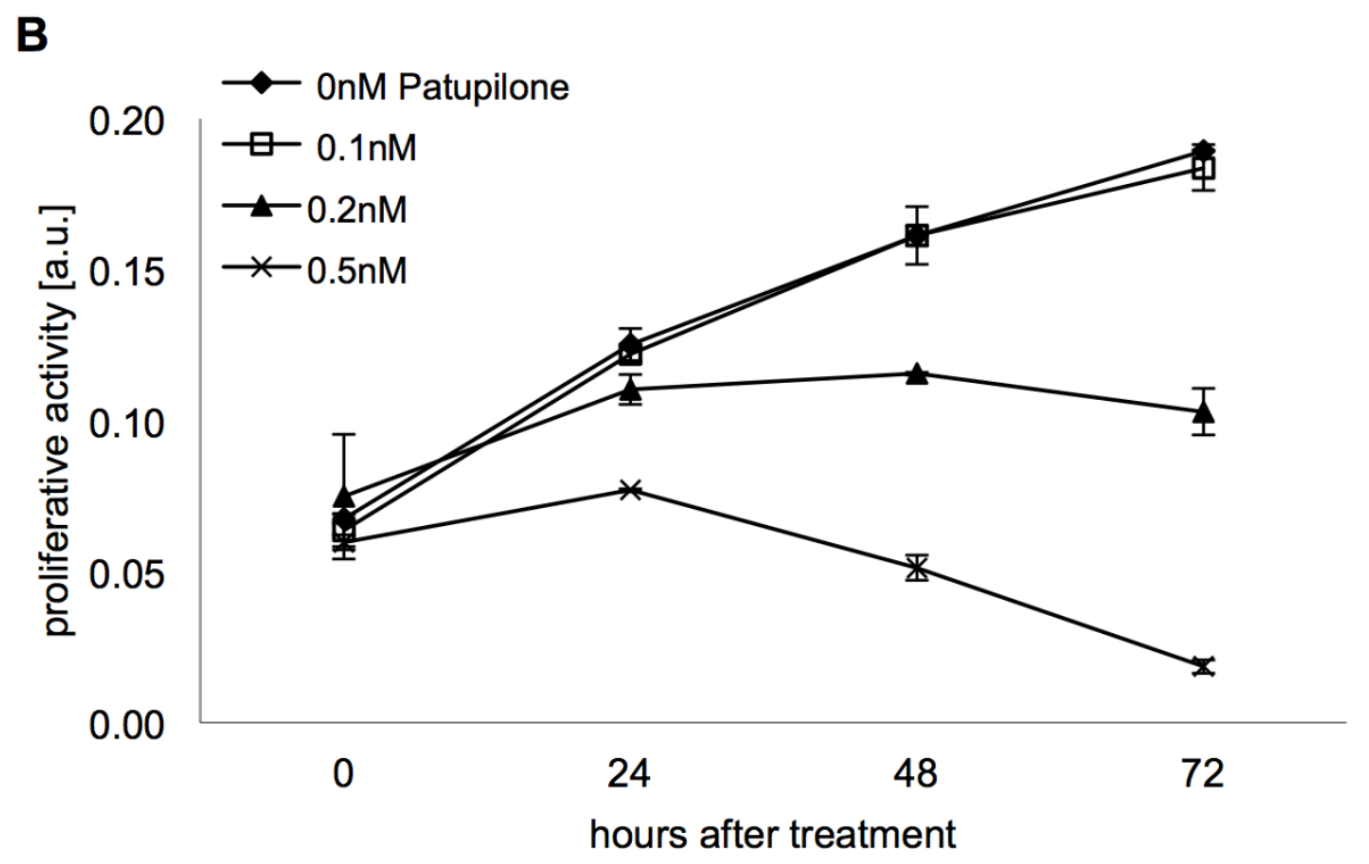

Figure 1: Proliferation activity after patupilone treatment was assessed over 72 hours using the alamarBlue ${ }^{\circledR}$ assay. Canine hemangiosarcoma (A) and malignant lymphoma cells (B) showed a $50 \%$ decrease of proliferative activity at 1 and $0.2 \mathrm{nM}$, respectively. Both graphs show a single representative experiment with inclusion of standard deviation. A.u.: artificial unit.

\section{In Vivo Study:}

Patient Characteristics. A total of 20 client-owned dogs were included in the study between July 2009 and October 2011. Patient population consisted of dogs of various breeds: mixed breed $(n=6)$, boxer $(n=3)$, golden retriever $(n=2)$, American pitbull, Jack Russell terrier, Australian, Belgian, German shepherd, Doberman pinscher, greater Swiss mountain dog, rottweiler, and standard poodle (one each). Median age upon study entry was 8.75 years (range 6-14 years) and median weight $28.4 \mathrm{~kg}$ (range 5.7-51.4 kg). Four dogs were intact females, two intact males, ten were spayed females and four castrated males. Different types of tumors were included; the most 
common primary tumors were malignant mammary carcinomas $(n=6)$, and malignant multicentric lymphoma $(n=6)$; two of the mammary tumors were diagnosed as anaplastic mammary adenocarcinoma. Other tumors included mast cell tumors $(n=3)$, prostate carcinoma $(\mathrm{n}=2)$, anal gland adenocarcinoma, oral malignant melanoma, and cardiac hemangiosarcoma (one each). The majority of dogs had received prior treatment with either chemotherapy $(n=10)$, surgery $(n=4)$, surgery and chemotherapy $(n=1)$ or radiation therapy $(n=1)$. All but one dog had measurable disease at the onset of patupilone treatment. 13/20 (65\%) showed macroscopic local or locoregional disease (one distant metastasis), 6/20 (30\%) had multicentric malignant lymphoma and one dog (5\%) showed microscopic disease after surgery of a large invasive mammary carcinoma. All six dogs with malignant lymphoma showed multicentric involvement stage IV-V, substage a-b disease and clinical resistance towards several previous chemotherapy protocols. Two dogs showed T-cell, two B-cell, one null-cell lymphoma, and in one dog immunophenotyping was not performed.

Drug Administration. Patients were divided into six different dose groups from 1.6 to $3.3 \mathrm{mg} / \mathrm{m}^{2}$ with increments of $20 \%$, except in the dose group 6 (see table 1). At the starting dose of 1.6 $\mathrm{mg} / \mathrm{m}^{2}$ only one dog was included; due to rapid disease progression and no drug-related AE, the second dog was treated with the next higher dose. The other groups included at least three dogs per dose level, with additional three (confirmatory) patients at the MTD level. In total, 62 patupilone doses were administered, with a median of three per dog (range 1-7). Eighteen dogs received one cycle of patupilone (as planned) and eleven of these continued treatment with the study drug. Two dogs received one patupilone treatment only, due to grade 2 AE and owner's decline for further treatment in one dog, and grade $3 \mathrm{AE}$ and exclusion of the study in another dog. Seven dogs received concurrent NSAIDs and eight received steroids. 
Table 1 Gastrointestinal adverse effects after patupilone treatment as classified by VCOGCTCAE v1.0. ${ }^{18}$

\begin{tabular}{|c|c|c|c|c|c|c|c|c|c|c|}
\hline Dose & Dose & $\overline{\text { Dogs }}$ & & & & & & & & \\
\hline \multirow[t]{3}{*}{ Group } & \multirow[t]{3}{*}{$\left(\mathrm{mg} / \mathrm{m}^{2}\right)$} & \multirow[t]{3}{*}{ (n) } & \multicolumn{2}{|c|}{ Diarrhea } & \multicolumn{2}{|c|}{ Anorexia } & \multicolumn{2}{|c|}{ Nausea } & \multicolumn{2}{|c|}{ Vomiting } \\
\hline & & & Grade & Grade 3 & Grade & Grade & Grade & Grade & Grade & Grade \\
\hline & & & $1+2(n)$ & (n) & $1+2(n)$ & $3(n)$ & $1+2(n)$ & $3(n)$ & $1+2(n)$ & $3(n)$ \\
\hline 1 & 1.6 & 1 & 1 & 0 & 1 & 0 & 1 & 0 & 1 & 0 \\
\hline 2 & 1.9 & 3 & 2 & 0 & 2 & 0 & 2 & 0 & 2 & 0 \\
\hline 3 & 2.3 & 3 & 2 & 0 & 2 & 0 & 2 & 0 & 0 & 0 \\
\hline 4 & 2.76 & 6 & 3 & 0 & $2 * * *$ & 0 & 3 & 0 & 5 & 0 \\
\hline 5 & 3.3 & 3 & 1 & 1 & 0 & 2 & 2 & 0 & 2 & 0 \\
\hline 6 & $3 *$ & 4 & $4 * *$ & 0 & $2 * * *$ & 1 & 3 & 0 & 4 & 0 \\
\hline Total & & 20 & 14 & 1 & 9 & 3 & 13 & 0 & 14 & 0 \\
\hline
\end{tabular}

AE: adverse effects

* Dose was reduced by $10 \%$ to approach the optimal dose more precisely.

** of which 2 were grade 2 leading to a relevant treatment delay of $\geq \mathbf{5}$ days

*** of which 1 was grade 2 leading to a relevant treatment delay of $\geq \mathbf{5}$ days

\section{Assessment of Adverse Effects:}

Metabolic AE were evaluable after 60 of the 62 drug administrations; data of all other AE was assessable after every patupilone administration.

Metabolic: Hematological and serum biochemical AE were mild, as summarized in table 2. In 9/13 dogs with anemia (17 administrations), grade 1 toxicosis was already present at study entry with no change during the study. Grade 1-2 thrombocytopenia occurred in three dogs with advanced malignant lymphoma; one of them had grade 1 impairment already at baseline and progressed to grade 2 after chemotherapy. No neutropenia was seen in any dog. All dogs with 
increase in alanine aminotransferase (ALAT) had received steroids for a prolonged period of time before study entry. Three dogs showed grade 3 increase in ALAT already at baseline and three dogs showed improvement or normalization of ALAT values at the end of chemotherapy. Gastrointestinal: Main AE in this study were diarrhea, anorexia, nausea, and vomiting. Doselimiting $\mathrm{AE}$ was determined to be anorexia and diarrhea. In affected dogs, diarrhea started with a median of four days after chemotherapy. Upon occurrence of gastrointestinal AE after the first drug administration, supportive care was administered in 14/20 (70\%) dogs. Not all AE were considered to be attributed to patupilone administration: in some dogs, toxicoses were considered to be attributed to disease progression or were considered to be due to treatment-unrelated comorbidities. However, all AE regardless of cause are listed in table 1. Other: Grade 1-2 fatigue was noted after 18/62 (29\%) drug administrations. In two dogs grade 1 fatigue was already present at study entry. A modified Karnofsky's performance status score of 1-2 was seen after 15/62 (24\%) treatments. In two dogs however, a performance status of 1 was already recorded at baseline. No other AE were noted. 
Table 2 Metabolic adverse effects according to VCOG-CTCAE v1.0 after all 60 evaluable drug administrations. ${ }^{18}$

\begin{tabular}{lcc}
\hline & $\begin{array}{c}\text { Highest Toxicity } \\
\text { Grade }\end{array}$ & Toxicities \\
& & $\begin{array}{c}\text { [occurrence of AE; } \\
\% \text { of all administrations] }\end{array}$ \\
\hline Anemia & 1 & $23(38 \%)$ \\
Thrombocytopenia & 2 & $3(5 \%)$ \\
Neutropenia & 0 & $0(0 \%)$ \\
Hypoalbuminemia & 1 & $2(3 \%)$ \\
Increase in Alanine & $3^{\text {a }}$ & $10(17 \%)$ \\
Aminotransferase & & \\
\hline AE: adverse effects &
\end{tabular}

MTD. Patupilone was well tolerated up to a dose of $2.76 \mathrm{mg} / \mathrm{m}^{2}$. At the next higher dose level of $3.3 \mathrm{mg} / \mathrm{m}^{2}$, two dogs showed dose-limiting grade 3 anorexia or anorexia and diarrhea, respectively. Dose was reduced by $10 \%$ to approach the optimal dose more precisely. At 3 $\mathrm{mg} / \mathrm{m}^{2}$, only one dog showed dose-limiting AE but the second application of chemotherapy had to be delayed for one week in two of the other dogs treated at this dose level due to grade 2 diarrhea or grade 2 diarrhea and anorexia,-respectively. Therefore, MTD for one cycle of patupilone was determined to be $2.76 \mathrm{mg} / \mathrm{m}^{2}$.

Tumor Response Assessment. Response was evaluated in 18/20 dogs. At the end of all patupilone treatments (range 1-7), three dogs (16.7\%) showed PR, six dogs (33.3\%) SD, and nine 
PD (50\%). The 3/11 dogs receiving more than one treatment cycle showed partial remission in the short period of observation and included a dog with prostate carcinoma and two dogs with anaplastic mammary carcinoma and sublumbar lymph node metastases. In the latter, surgical excision of the primary tumor was performed two weeks prior to study entry. Both dogs showed recurrence at the site of surgery and experienced PR after administration of more than two patupilone administrations.

\section{Discussion}

According to this phase I trial, the administration of patupilone up to an IV dose of $2.76 \mathrm{mg} / \mathrm{m}^{2}$ was found to be safe in dogs with spontaneously occurring tumors and no hypersensitivity reactions were observed. This is in contrast to taxoid MSA such as paclitaxel and docetaxel where the use in dogs is limited due to the requirement of organic solvents that cause unwanted side effects even in dogs that are heavily pre-medicated. ${ }^{24,25,26}$

In the in vitro part of this trial, canine tumor cells showed a strong decrease in proliferative activity with low doses of patupilone, $(1 \mathrm{nM}$ and $0.2 \mathrm{nM}$ in canine hemangiosarcoma and lymphoma cells, respectively), when compared to known patupilone-sensitive and -resistant human cell lines. ${ }^{23}$ In humans, a patupilone dose of $10 \mathrm{nM}$ is considered to be an in vitro approximation of plasma levels at a MTD of $2.5 \mathrm{mg} / \mathrm{m}^{2}{ }^{6,27}$ In an in vivo model with human colon tumor xenografts patupilone administration resulted in high concentration in tumor tissue at 168 hours after chemotherapy, while other tissues showed decreased concentrations. ${ }^{22}$ The presence of continuous drug exposure might contribute to tumor cell cytotoxicity and add to the prior described antiangiogenic efficacy of the drug. ${ }^{6,23,28}$ The MTD for two patupilone IV administrations given once weekly is $2.76 \mathrm{mg} / \mathrm{m}^{2}$, comparable to the dose in human patients for weekly administration. ${ }^{29}$ If patupilone is given at longer intervals, a higher dose is tolerated in 
man, as the severity of gastrointestinal signs can be controlled by proactive, aggressive diarrheamanagement. ${ }^{30}$ However, the main goal of this trial was to find MTD after one treatment cycle of patupilone (two administrations). One reason for the chosen schedule of two administrations aimed at being able to exploit not only the cytotoxic effect of the drug but also make use of the antiangiogenic and antivascular effects of epothilone B. Agents with antiangiogenic effects exert their efficacy after repeated administration of low doses with short interval in between, for example daily or weekly treatment. ${ }^{31}$ A second reason for this schedule was the intention to use the drug as a radiosensitizer in combined treatment with ionizing radiation. Epothilones are considered to be optimal radiosensitizing drugs as they induce cell cycle block in the most radiosensitive $\mathrm{G}_{2} / \mathrm{M}$-phase already at low and non-cytotoxic doses. This led to additive or even supraadditive effect on tumor growth in mice with human cancer xenografts. ${ }^{23,32,33}$ Hematological AE were generally mild and no neutropenia was seen. One treatment cycle of patupilone is therefore not associated with clinically significant myelosupression in dogs. The clinically relevant toxicosis in this study ( $\geq$ grade 2 ) was gastrointestinal, seen in $50 \%$ of all patients with main AE anorexia and/or diarrhea. However, in six dogs, mild pretreatment gastrointestinal impairment existed at study entry and might have had an effect on occurrence and severity of AE. Not all AE were considered to be due to the study drug, however, differentiation between drug-associated and drug-unrelated toxicosis is difficult, and therefore all AE were listed regardless of suspected cause. This toxicity profile resembles the one in human patients but in contrast to humans, no peripheral neuropathy was noted after up to seven patupilone administrations. ${ }^{30}$ Pathogenesis of neuropathy in chemotherapeutics that target microtubules is not entirely clear but can be explained by the disturbance of microtubule function and interference of the axonal transport. ${ }^{34}$ Although no neurological AE were noted in this study with 
a median of 3 patupilone administrations, mild symptoms might have been overlooked and cumulative toxicosis could occur.

$75 \%$ of the dogs received either steroids or NSAIDs. These drugs have a possible antitumor effect in certain tumor types, such as steroids in malignant lymphoma and NSAIDs in transitional cell carcinoma of the bladder and prostate carcinoma. ${ }^{35,36}$ Most dogs experienced disease progression while under these drugs before study entry. However, in four dogs these substances were prescribed shortly before inclusion into the study. A possible positive influence on response due to these drugs cannot be excluded in these cases.

This study was a dose-escalating trial; therefore many animals received low dosages of patupilone and most of the dogs were heavily pretreated and suffered from advanced disease state. Therefore response assessment was not a primary goal of this trial. A limitation of this study was the short observation of response and the lack of a defined period of time in order to count as a response. But partial remission in tumors that are difficult to treat (prostate and anaplastic mammary carcinoma) was unexpected and was interpreted as promising.

Patupilone is a new antineoplastic agent with a manageable toxicity profile and a promising antitumor response in dogs with spontaneously occurring tumors. As patupilone induces an arrest at the most radiosensitive phase of cell cycle $\left(\mathrm{G}_{2} / \mathrm{M}\right)$, it is an ideal radiosensitizer showing supraadditive efficacy in mice. ${ }^{2,23,32,33}$ Furthermore, patupilone possesses antimetastatic and antiangiogenic properties, is able to cross the blood brain barrier and is not susceptible to pglycoprotein-overexpression-mediated chemoresistance. ${ }^{2,37}$ This makes it a promising agent for single and combined modality treatment.

\footnotetext{
${ }^{\mathrm{a}}$ Ixempra $^{\mathrm{TM}}$, Bristol-Myers Squibb Company, Princeton, USA

${ }^{\mathrm{b}-\mathrm{h}}$ Invitrogen, Lucerne, Switzerland
} 
${ }^{i-j}$ Bucher Biotec AG, Basel, Switzerland

\section{References:}

1. Jordan M, Wilson L. Microtubules as a target for anticancer drugs. Nat Rev Cancer 2004;4:253-265.

2. Bollag D, McQueney P, Zhu J, et al. Epothilones, a new class of microtubule-stabilizing agents with a taxol-like mechanism of action. Cancer Res 1995;55:2325-2333.

3. Gradishar W. Management of advanced breast cancer with the epothilone B analog, ixabepilone. Drug Des Devel Ther 2009;3:163-171.

4. Bystricky B, Chau I. Patupilone in cancer treatment. Expert Opin Investig Drugs 2011;20:107117.

5. Bocci G, Nicolaou K, Kerbel R. Protracted low-dose effects on human endothelial cell proliferation and survival in vitro reveal a selective antiangiogenic window for various chemotherapeutic drugs. Cancer Res 2002;62:6938-6943.

6. Woltering E, Lewis J, Maxwell P, et al. Development of a novel in vitro human tissue-based angiogenesis assay to evaluate the effect of antiangiogenic drugs. Ann Surg 2003;237:790-798; discussion 798-800.

7. Ferretti S, Allegrini P, O'Reilly T, et al. Patupilone induced vascular disruption in orthotopic rodent tumor models detected by magnetic resonance imaging and interstitial fluid pressure. Clin Cancer Res 2005;11:7773-7784.

8. Fogh S, Machtay M, Werner-Wasik M, et al. Phase I trial using patupilone (epothilone B) and concurrent radiotherapy for central nervous system malignancies. Int J Radiat Oncol Biol Phys 2010:77:1009-1016. 
9. Freedman R, Bullitt E, Sun L, et al. A phase II study of sagopilone (ZK 219477; ZK-EPO) in patients with breast cancer and brain metastases. Clin Breast Cancer 2011:11:376-383.

10. Rustin G, Reed N, Jayson G, et al. A phase II trial evaluating two schedules of sagopilone (ZK-EPO), a novel epothilone, in patients with platinum-resistant ovarian cancer. Ann Oncol 2011;22:2411-2416.

11. Stupp R, Tosoni A, Bromberg J, et al. Sagopilone (ZK-EPO, ZK 219477) for recurrent glioblastoma. A phase II multicenter trial by the European organisation for research and treatment of cancer (EORTC) brain tumor group. Ann Oncol 2011;22:2144-2149.

12. Dumontet C, Jordan M. Microtubule-binding agents: a dynamic field of cancer therapeutics. Nat Rev Drug Discov 2010;9:790-803.

13. Momoi Y, Okai Y, Watari T, et al. Establishment and characterization of a canine Tlymphoblastoid cell line derived from malignant lymphoma. Vet Immunol Immunopathol 1997;59:11-20.

14. Fosmire S, Dickerson E, Scott A, et al. Canine malignant hemangiosarcoma as a model of primitive angiogenic endothelium. Lab Invest 2004;84:562-572.

15. Chretin J, Rassnick K, Shaw N, et al. Prophylactic trimethoprim-sulfadiazine during chemotherapy in dogs with lymphoma and osteosarcoma: a double-blind, placebo-controlled study. J Vet Intern Med 2007;21:141-148.

16. Le Tourneau C, Lee J, Siu L. Dose escalation methods in phase I cancer clinical trials. J Natl Cancer Inst 2009;101:708-720.

17. Vail D. Cancer clinical trials: development and implementation. Vet Clin North Am Small Anim Pract 2007;37:1033-1057. 
18. Vail D. Veterinary co-operative oncology group - common terminology criteria for adverse events (VCOG-CTCAE) following chemotherapy or biological antineoplastic therapy in dogs and cats v1.0. Vet Comp Oncol 2004;2:195-213.

19. Vail D, Michels G, Khanna C, et al. Response evaluation criteria for peripheral nodal lymphoma in dogs (v1.0)--a veterinary cooperative oncology Group (VCOG) consensus document. Vet Comp Oncol 2010;8:28-37.

20. Eisenhauer E, Therasse P, Bogaerts J, et al. New response evaluation criteria in solid tumours: revised RECIST guideline (version 1.1). Eur J Cancer 2009;45:228-247.

21. Crowley E, Callaghan R. Multidrug efflux pumps: drug binding-gates or cavity? FEBS J 2010;277:530-539.

22. O'Reilly T, Wartmann M, Brueggen J, et al. Pharmacokinetic profile of the microtubule stabilizer patupilone in tumor-bearing rodents and comparison of anti-cancer activity with other MTS in vitro and in vivo. Cancer Chemother Pharmacol 2008;62:1045-1054.

23. Bley C, Jochum W, Orlowski K, et al. Role of the microenvironment for radiosensitization by patupilone. Clinical Cancer Research 2009;15:1335-1342.

24. Edelman M. Novel taxane formulations and microtubule-binding agents in non-small-cell lung cancer. Clin Lung Cancer 2009;10 Suppl 1:S30-34.

25. Poirier V, Hershey A, Burgess K, et al. Efficacy and toxicity of paclitaxel (taxol) for the treatment of canine malignant tumors. J Vet Intern Med 2004;18:219-222.

26. Simon D, Schoenrock D, Baumgartner W, Nolte I. Postoperative adjuvant treatment of invasive malignant mammary gland tumors in dogs with doxorubicin and docetaxel. J Vet Intern Med 2006;20:1184-1190.

27. Stalder M, Anthony C, Woltering E. Metronomic dosing enhances the anti-angiogenic effect of epothilone B. J Surg Res 2009:169:247-256. 
28. Pasquier E, Honore S, Pourroy B, et al. Antiangiogenic concentrations of paclitaxel induce an increase in microtubule dynamics in endothelial cells but not in cancer cells. Cancer Res 2005;65:2433-2440.

29. Rubin E, Rothermel J, Tesfaye F, et al. Phase I dose-finding study of weekly single-agent patupilone in patients with advanced solid tumors. J Clin Oncol 2005;23:9120-9129.

30. Ten Bokkel Huinink W, Sufliarsky J, Smit W, et al. Safety and efficacy of patupilone in patients with advanced ovarian, primary fallopian, or primary peritoneal cancer: a phase I, openlabel, dose-escalation study. J Clin Oncol 2009;27:3097-3103.

31. Kerbel R, Kamen B. The anti-angiogenic basis of metronomic chemotherapy. Nat Rev Cancer 2004;4:423-436.

32. Hofstetter B, Vuong V, Broggini-Tenzer A, et al. Patupilone acts as radiosensitizing agent in multidrug-resistant cancer cells in vitro and in vivo. Clin Cancer Res 2005;11:1588-1596.

33. Rohrer Bley C, Orlowski K, Furmanova P, et al. Regulation of VEGF-expression by patupilone and ionizing radiation in lung adenocarcinoma cells. Lung Cancer 2011;73:294-301.

34. Argyriou A, Marmiroli P, Cavaletti G, Kalofonos H. Epothilone-induced peripheral neuropathy: a review of current knowledge. J Pain Symptom Manage 2011;42:931-940.

35. Knapp D, Richardson R, Chan T, et al. Piroxicam therapy in 34 dogs with transitional cell carcinoma of the urinary bladder. J Vet Intern Med 1994;8:273-278.

36. Sorenmo K, Goldschmidt M, Shofer F, et al. Evaluation of cyclooxygenase-1 and cyclooxygenase- 2 expression and the effect of cyclooxygenase inhibitors in canine prostatic carcinoma. Vet Comp Oncol 2004;2:13-23.

37. Fogh S, Machtay M, Werner-Wasik M, et al. Phase I trial using patupilone (epothilone B) and concurrent radiotherapy for central nervous system malignancies. Int J Radiat Oncol Biol Phys 2010;77:1009-1016. 


\section{Lebenslauf}

$\begin{array}{ll}\text { Name } & \text { Valeria Sabina, Meier } \\ \text { Geburtsdatum } & 20.05 .1983 \\ \text { Geburtsort } & \text { Zürich } \\ \text { Nationalität } & \text { CH } \\ \text { Heimatort } & \text { Hundwil AR }\end{array}$

08/1990 - 07/1996 Primarschule Schulhaus Scherr, Zürich, Schweiz

08/1996 - 09/2003 Kantonsschule Hohe Promenade, Zürich, Schweiz

08/2000 - 08/2001 Auslandsjahr an der St. Johns High School, St. Jean-sur-Richelieu, QC, Kanada

06/2001 Abschluss der High School mit der Graduation an der St. Johns High School, St. Jean-sur-Richelieu, QC, Kanada

05/09/2003 Maturität, neusprachliches Profil (Englisch, Italienisch) an der

Kantonsschule Hohe Promenade, Zürich, Schweiz

10/2003 - 10/2009 Studium der Veterinärmedizin mit dem Schwerpunkt Kleintiere an der Vetsuisse-Fakultät Universität Zürich, Schweiz

15/09/2009 Abschluss des Veterinärmedizinstudiums mit dem Staatsexamen an der Vetsuisse-Fakultät Universität Zürich, Schweiz

11/2009-10/2011 Anfertigung der Dissertation unter Leitung von PD Dr. med. vet., Dipl. ACVR (Radiation Oncology) Carla Rohrer Bley, am Departement für Kleintiere, Abteilung für RadioOnkologie der Vetsuisse-Fakultät der Universität Zürich, Direktor Prof. Dr. med. vet., MSc, Dipl. ACZM, Dipl. ECZM (Avian) Jean-Michel Hatt

11/2009 - 10/2011 Assistenztierärztin und Doktorandin am Departement für Kleintiere, Abteilung für Radio-Onkologie der Vetsuisse-Fakultät der Universität Zürich, Schweiz

11/2011 - heute Assistenztierärztin mit Schwerpunkt Strahlentherapie am Departement für Kleintiere, Abteilung für Radio-Onkologie der Vetsuisse-Fakultät der Universität Zürich, Schweiz 


\section{Danksagung}

Ich möchte mich ganz herzlich bei meiner Referentin und Betreuerin PD Dr. Carla Rohrer Bley bedanken. Sie hat meine vielen Fragen kompetent und immer geduldig beantwortet, hat mich ermuntert selbstständig zu arbeiten, mir aber auch unter die Arme gegriffen, wenn ich alleine nicht mehr weiter wusste. Nebenbei hat sie mir viele wichtige Ratschläge für eine effiziente Arbeitsweise und die Erstellung eines wissenschaftlichen Projekts mit auf den Weg gegeben. Durch ihren Enthusiasmus und die lebhaften Diskussionen im gemeinsamen Büro hat sie ausserdem mein Interesse für die Wissenschaft und für die Radio-Onkologie im speziellen geweckt.

Auch beim gesamten Team der Radio-Onkologie möchte ich mich ganz herzlich bedanken. Sie haben mich vor allem im klinischen Bereich unterstützt und mich viel gelehrt, haben mich aber auch nie das Lachen vergessen lassen.

Mein besonderer Dank geht auch an meine Familie und meinen Freund Dominik Tasnady. Sie alle haben ermöglicht, dass ich eine Dissertation schreiben und mein Interesse für die Forschung entdecken durfte. Sie haben mir den Rücken gestärkt und sich jedes Mal mit mir gefreut, wenn ich einen Schritt weitergekommen bin. 